\title{
Learning Perspectives of Publication
}

\author{
Joel Rey U Acob* \\ College of Nursing, Visayas State \\ University, Visca, City of Baybay \\ Leyte, Philippines \\ *Correspondence: Joel Rey U Acob \\ College of Nursing, Visayas State \\ University, Visca, City of Baybay \\ Leyte, Philippines \\ Email: joel.acob@vsu.edu.ph
}

Volume 1(1), 23-24

(c) The Author(s) 2022

http://dx.doi.org/10.55048/jpns.v1i1.4

e-ISSN 2827-8100

p-ISSN 2827-8496

Received : January 3, 2021

Accepted : January 4, 2022

Published: January 22, 2022

\section{(c) (i) ()}

This is an Open Access article distributed under the terms of the Creative Commons Attribution-NonCommercial 4.0 International License.

\begin{abstract}
The growing demand of scientific-driven results to strengthen nursing profession, researchers should consistently engage in executing knowledge-generating actions. Disseminating research results either through fora or in printed publication deepens understanding on issues particularly on caring and nursing education. But will research endures its aim of offering relevant evidence during pandemic era where conventional data collection strategies are less feasible, hence this viewpoint.
\end{abstract}

Keywords: caring; education; nursing; research; publication

Neophyte researchers are eyes-focused on publishing to high impact journals. Although this poses no problem, if it prohibits one from disseminating their works, then a new perspective should be considered. Publication's genuine intention is knowledge propagation, endorse critical attention, health and wellbeing (Fortney, 2021) and it has not changed since then. Exploring while attempting to produce ideas through the empirical manner in early phases become vital works in research progression. Findings explaining the phenomenon and putting meaning and new interpretations to research-driven data necessitate the art of publication.

Putting a premium on the work, considering how research results impact fellows, adding credibility every time researchers releases findings are some of-the-many significances to publish. Nursing, chiefly known as an evidence-based profession, demands scientific knowledge. Research similarly plays a critical part in rendering nursing care, transacting empathy (Martiningsih et al., 2021) and reports one's mental health especially in the light of the pandemic across the population (Nugroho et al., 2021). Therefore, the publishing message must cut across the globe; the mark is dissemination, not primarily on the journal.

Since all faculty members want to publish, its mechanisms are not as easy as eating peanuts. Learning disciplines must transpire for an academic institution to prosper in publication. Structuring shared vision primarily must be defined. Assessment in the nursing process speaks similarly whereby institutions

Acob, J. R. U. (2022). Learning Perspectives of Publication. The Journal of Palembang Nursing Studies. 1(1): 23-24. http://dx.doi. org/10.55048/jpns.v1i1.4 
should understand the commonality of purpose to transform nursing practice and education (Acob, 2019). Where is the organization going in terms of publication endeavors? Each one must contribute commitment to the better changing nursing environment by broadcasting newer knowledge from and into the workplace. The second is demarcating how research findings affect both the organization, consumers of knowledge to grow, change and improve.

By cyclical writing-publishing modes, researchers obtain mastery and a personal sense of satisfaction as this emphasizes pride to better the work while readers adapt and grow in caring. New findings and updated versions of work firm vision or outcome for patient quality care. Collaboration and the climate of shared works are enhanced when one attempts to learn to publish. These systems thinking produce a better future to integrate the complex yet adaptive publication disciplines.

Finally, academic institutions must condition the mindset that research is not only for teachers, more-so for students to love and be involved with. They are conducting quality papers while empowering them about the process to solve day-to-day community issues in a more realizable and meaningful way.

\section{Declaration of Interest}

None

\section{Acknowledgment}

None

\section{Funding}

None

\section{Data Availability}

None

\section{REFERENCES}

Acob, J. R. U. (2019). Transforming Nursing Education and Practice: a Review on the Innovation Strategy towards Sustainable Primary Healthcare Workforce. Indian Journal of Forensic Medicine and Toxicology, 13(4), 1674-1677. https://doi. org/10.5958/0973-9130.2019.00546.2

Fortney, C. A. (2021). Importance of Publication of Articles Discussing Ethics and Ethical Challenges. Advances in neonatal care : official journal of the National Association of Neonatal Nurses, 21(6), 425-426. $\quad$ https://doi.org/10.1097/ ANC.0000000000000965

Martiningsih, W., Winarni, S., Acob, J. R., Baua, M. E., \& Nugroho, H. (2021). Transactional Self Care and Empathy Theory in Nursing (A Perspective). Open Access Macedonian Journal of Medical Sciences, 9(G), 273-280. https://doi. org/10.3889/oamjms.2021.7278

Nugroho, H.S. W., Acob, J. R. U., \& Martiningsih, W. (2021). Healthcare Worker's Mental Health During the Epidemic Peak of COVID-19 [Letter]. Psychology Research and Behavior Management. 2021(14), 333-334. https://doi.org/ https://doi.org/10.2147/PRBM.S309309 